College of William \& Mary Law School William \& Mary Law School Scholarship Repository

1996

\title{
The Failure of the Religious Freedom Restoration Act Under Section 5 of the Fourteenth Amendment
}

William W. Van Alstyne

William \& Mary Law School

\section{Repository Citation}

Van Alstyne, William W., "The Failure of the Religious Freedom Restoration Act Under Section 5 of the Fourteenth Amendment" (1996). Faculty Publications. 685.

https://scholarship.law.wm.edu/facpubs/685

Copyright c 1996 by the authors. This article is brought to you by the William \& Mary Law School Scholarship Repository. https://scholarship.law.wm.edu/facpubs 
Essay

\title{
THE FAILURE OF THE RELIGIOUS FREEDOM RESTORATION ACT UNDER SECTION 5 OF THE FOURTEENTH AMENDMENT
}

\author{
WILLIAM W. VAN ALSTYNE ${ }^{\dagger}$
}

The powers not delegated to the United States by the Constitution, nor prohibited by it to the States, are reserved to the States respectively, or to the people. ${ }^{1}$

The generalities of the Fourteenth Amendment are so indeterminate as to what state actions are forbidden that this Court has found it a ready instrument, in one field or another, to magnify federal, and incidentally its own, authority over the states.... There is no doubt that if there were a super-Supreme Court, a substantial proportion of our [decisions respecting what the states may or may not do consistent with the Fourteenth Amendment] would also be reversed. We are not final because we are infallible, but we are infallible only because we are final. ${ }^{2}$

[T]his act reverses the Supreme Court's decision Employment Division against Smith ....3

$\dagger$ William R. Perkins Professor of Law, Duke University (with appreciation to Erika King for research and editorial assistance).

1. U.S. CONST. amend. X.

2. Brown v. Allen, 344 U.S. 443, 534, 540 (1953) (Jackson, J., concurring); see also Marbury v. Madison, 5 U.S. (1 Cranch) 137, 177 (1803) ("It is emphatically the province and duty of the judicial department to say what the law is.").

3. President's Remarks on Signing the Religious Freedom Restoration Act of 1993, 2 PUB. PAPERS 2000 (Nov. 16, 1993). The text of the Religious Freedom Restoration Act (RFRA), 42 U.S.C. $\S 2000 \mathrm{bb}$ (1994), is reprinted infra as an Appendix. 


\author{
I.
}

A.

Suppose at the outset of a state criminal homicide prosecution, the defendant moves to exclude incriminating evidence ${ }^{4}$ the police had found in an open field on his property, just inside the fence. In moving to suppress, the defendant relies on the Fourth Amendment $t^{5}$ as applied to the states via the Due Process Clause of the Fourteenth Amendment. ${ }^{6} \mathrm{He}$ submits that, because the police entered the field without a search warrant, the "fruits of the search," i.e., the gun, must be suppressed. The State demurs on the ground that no warrant was required to search the field-the defendant is simply mistaken in suggesting otherwise. ${ }^{7}$ The state court, however, accepts the defendant's view that the Supreme Court case supporting the State's position has been called into serious question. ${ }^{8}$ Admitting the issue is uncertain, the state court nonetheless rules in the defendant's favor. It therefore grants the motion to suppress.

Following ineffective interlocutory appeal by the State through the state courts, the case then arrives, via petition of the State, at the United States Supreme Court, to review the critical state court ruling on the Fourth Amendment question. The Supreme Court reverses in an opinion by the Chief Justice (seven justices concur-

4. Such evidence might be, for example, the discarded gun used to kill the victim (as confirmed in ballistic tests), which is registered to the defendant and bears powder traces exactly matching traces found on the defendant's hand.

5. The Fourth Amendment reads:

The right of the people to be secure in their persons, houses, papers, and effects, against unreasonable searches and seizures, shall not be violated, and no Warrants shall issue, but upon probable cause, supported by Oath or affirmation, and particularly describing the place to be searched, and the persons or things to be seized.

6. For the proposition that the Fourteenth Amendment's Due Process Clause makes applicable to the states the Fourth Amendment provisions regarding searches and seizures, the defendant rightly relies on Ker v. California, 374 U.S. 23 (1963), and Mapp $v$. Ohio, 367 U.S. 643 (1961).

7. The State notes that the Fourth Amendment does not extend to open fields, whether fenced or not, citing Hester v. United States, 265 U.S. 57, 59 (1924) (Holmes, J.) ("TT]he special protection accorded by the Fourth Amendment to the people in their 'persons, houses, papers, and effects,' is not extended to the open fields.").

8. Most notably, perhaps, by Katz v. United States, 389 U.S. 347, 353 (1967) (holding that the Fourth Amendment warrant requirement does extend to surreptitious wiretapping of ordinary pay phones, and declaring that the Fourth Amendment protects people, not places). 
ring, one dissenting) and remands the case for trial. It holds that no warrant was required. ${ }^{9}$ The Court sums up:

A state court does not deprive a person of liberty "without due process" merely by admitting evidence against him which was found by police in the course of an open field search. The State commits no constitutional wrong under the Fourth Amendment in having acquired evidence in this manner, for we hold the Fourth Amendment is inapplicable in these circumstances. So, too, the State commits no constitutional wrong under the Fourteenth Amendment, which merely applies the Fourth Amendment equally to the states. Accordingly, the state law (here, its law of criminal procedure) governing the admissibility of such evidence does not as applied infringe any due process right of the accused. The decision below is reversed, the judgment vacated, and the case remanded for trial.

Against the background of this clear holding from the Court, we now turn to an act of Congress that presumes to dictate the opposite outcome-i.e., an act directing the exclusion of the incriminating evidence in the remanded state court proceedings, ${ }^{10}$ despite the State's successful appeal to the Supreme Court.

Enacted the year following the Supreme Court's decision, the act reflects Congress' disapproval of any state that would presume to take seriously-much less in any way rely on-the view of the Supreme Court (rather than the dissent) as a "correct" statement of "the law." Congress first expresses its disdain for the Supreme Court's opinion and, having done so, moves to enact the dissent, recast in the following words:

No court of any state shall admit as evidence in any civil or criminal proceeding anything taken from any field owned by one who has not consented to its search, absent a warrant issued by a neutral magistrate on a finding of probable cause.

The obvious question promptly presents itself. For at once the State wants to know on what basis Congress presumes to command its courts and dictate its rules of evidence in this way. ${ }^{11}$

9. See Oliver v. United States, 466 U.S. 170, 176-77 (1984) (reaffirming the holding in Hester v. United States, 265 U.S. 57, 59 (1924), and declining to confer Fourth Amendment sanctuary on open fields remote from houses).

10. And the consequent release of the person charged with homicide (because of the compelled suppression of the most critical evidence tending to establish his guilt).

11. The question raised by the State concerns the entitlement of Congress to set 
Note that the state presenting this question is not interested in whether Congress might prescribe such a rule merely to govern the admissibility of evidence in the federal courts. ${ }^{12}$ It readily recognizes that pursuant to provisions in Article III of the Constitution and the Necessary and Proper Clause in Article I, Congress

aside the Supreme Court's authoritative adjudication of the Due Process Clause, and to mandate that, instead, all state courts (and presumably then all federal courts examining the state court conviction on collateral attack) shall treat the case just reviewed as though it involved a violation of the Fourteenth Amendment, though none of these courts would otherwise so conclude. The State, in raising this question, does nothing at all remarkable. The Supreme Court readily recognizes the legitimacy of the inquiry. See Kansas v. Colorado, 206 U.S. 46, 89 (1907) ("[T]he proposition that there are legislative powers ... not expressed in the grant of powers [to Congress], is in direct conflict with the doctrine that this is a government of enumerated powers."); United States v. Fisher, 6 U.S. (2 Cranch) 358, 395 (1805) ("[U]nder a constitution conferring specific powers, the power contended for must be granted, or it cannot be exercised."); 2 ElloTT's DEBATES 489 (2d ed. 1836) (comments of James Wilson regarding Pennsylvania's adoption of the Constitution) ("If a law should be made inconsistent with those powers vested by this instrument in Congress, the judges, as a consequence of their independence, and the particular powers of government being defined, will declare such law to be null and void ....".).

12. Similarly, to the extent the RFRA itself merely prescribes a rule of construction regarding the manner in which other acts of Congress are to be applied, it is unremarkable. It is simply of no consequence why Congress prescribes a rule specifying how its own statutes are to be applied. Specifically, whether Congress so provided merely from political desire to ingratiate itself (or its incumbent members) with various religious organizations, for example, or even from a view that the spirit of the First Amendment is somehow best served by exempting one class of citizens from laws that all others must obey, is not a critical or even relevant issue for the courts. For the courts, rather, it is quite enough that Congress has the power to enact such a provision (which it doubtless does) and that, as enacted-solely to declare how federal statutes are to be affected-the RFRA does not so favor religion as to run afoul of the Establishment Clause (or the implied Equal Protection Clause of the Fifth Amendment). See EEOC v. Catholic Univ. of Am., 83 F.3d 455, 470 (D.C. Cir. 1996) (dicta sustaining the RFRA merely as a directive by Congress regarding the manner in which acts of Congress shall be applied, finding this within congressional authority under the Constitution).

For suggestions that such purely religious exemptions from laws binding on all others are not easily reconcilable with the Establishment Clause of the First Amendment and the implied Equal Protection Clause of the Fifth Amendment, see Welsh v. United States, 398 U.S. 333, 344-67 (1970) (Harlan, J., concurring), Walz v. Tax Commission, 397 U.S. 664, 694-700 (1970) (Harlan, J., concurring), and Sherbert v. Verner, 374 U.S. 398, 418-23 (1963) (Harlan, J., dissenting). A majority of the Court, however, treats them as permissible, albeit within certain limits. Compare Trans World Airlines, Inc. v. Hardison, 432 U.S. 63, 72, 81, 85 (1977) (holding that Title VII of the Civil Rights Act of 1964, by calling for reasonable rather than absolute accommodation and extending that requirement to all religious beliefs and practices rather than protecting only Sabbath observance, is an anti-discrimination law rather than an endorsement of religion and therefore is valid under the Establishment Clause), with Estate of Thomton v. Caldor, Inc., 472 U.S. 703, 710-11 (1985) (striking, on Establishment Clause grounds, a Connecticut statute that provided Sabbath observers with an absolute right not to work on their Sabbath). 
may prescribe such rules of evidence, generally, as it thinks appropriate. ${ }^{13}$ All concede, however, that Congress is given no such power in respect to the states, their rules of evidence, or their courts. ${ }^{14}$

After conceding this general point when the case is on remand to the trial court, counsel for the defendant says the following:

The answer to that question is ... that the power to adopt this act requiring this court to exclude the evidence in question ... well, it comes from the last section of the Fourteenth Amendment itself. And insofar as Congress is given this kind of power pursuant to Section 5 of the Fourteenth Amendment, and has exercised it to prevent this court from considering this evidence, its act forbidding consideration of this evidence is necessarily entitled to control in the state courts pursuant to the Supremacy Clause in Article VI.

Well, we quite agree with defense counsel as to the Supremacy Clause in Article VI. But, of course, that clause is not the source of Congress' power to have adopted this (or any other) act. ${ }^{15}$ As to that, we must look to the other part of the answer provided. Puzzled by counsel's response, but interested to see whether he could possibly be correct, we turn to the section of the Constitution that he has invoked for the act of Congress, and we read it. This is what Section 5 of the Fourteenth Amendment says:

13. See Palermo v. United States, 360 U.S. 343, 353 n.11 (1959) ("Congress has the power to prescribe rules of procedure for the federal courts, and has from the earliest days exercised that power. . . . The power of this Court to prescribe rules of procedure and evidence for the federal courts exists only in the absence of a relevant Act of Congress."). And whether Congress puts the explanation for its rules of evidence on the ground of mere policy preference rather than anything more profound (such as a belief that they-or some of them-are constitutionally required) is, for the courts, really neither here nor there. There are, of course, limits to Congress' power to prescribe procedures and rules of evidence, see, e.g., United States v. Klein, 80 U.S. (13 Wall.) 128, 146 (1872), but none would be implicated by a rule of the sort here.

14. See, e.g., New York v. United States, 505 U.S. 144, 162 (1992) ("[T]he Constitution has never been understood to confer upon Congress the ability to require the States to govem according to Congress' instructions.").

15. Rather, Article VI merely provides: "This Constitution, and the Laws of the United States which shall be made in Pursuance thereof . . . shall be the supreme Law of the Land; and the Judges in every State shall be bound thereby, any Thing in the Constitution or Laws of any State to the Contrary notwithstanding." (emphasis added). 
The Congress shall have the power to enforce, by appropriate legislation, the provisions of this article. ${ }^{16}$

And the question immediately prompts itself: What "provision," if any, of "this article," does this act of Congress merely "enforce" $?^{17}$

It may be the case-indeed, it probably is the case-that the clause commits to Congress the authority to provide for the punishment of local law enforcement personnel who conduct unlawful searches and seizures (i.e., those pursued in disregard of Fourth Amendment restrictions applicable to the states by force of Section 1 of the Fourteenth Amendment). Such a law, were it adopted by Congress, might well forcefully illustrate what it means to say (as Section 5 does say) that Congress shall have power to "enforce" (i.e., compel observance of) that which the Fourteenth Amendment enjoins. ${ }^{18}$ And, in order to further deter unlawful searches and seizures, possibly Congress could, by statute, forbid the state's use of evidence wrongly obtained by the police (i.e., obtained by means that the Fourth and Fourteenth Amendments disallow).

Here, however, Congress has done neither of these things, nor anything even faintly like them. Rather, Congress has claimed no less than an authority to review the Supreme Court for constitutional error. This is the power Congress now claims:

Whether or not the Supreme Court is of the view that the Fourteenth Amendment does not forbid open field searches absent consent of the owner or a warrant issued by a neutral magistrate on a showing of probable cause, we think (or at least we are prepared to declare) that it would be a better interpretation of the Fourteenth Amendment if it did. And we shall treat the

16. U.S. CONST. amend. XIV, \& 5.

17. That is, what provision does the act merely compel the state scrupulously to respect (or hold the state accountable for failing to respect)? The standard dictionary definition of "enforce" is merely "[t]0 compel observance of or obedience to." AMERICAN HERITAGE DICTIONARY 610 (3d ed. 1992). The same term, "enforce," appears in matching clauses of several other amendments as well. See U.S. CONST. amend. XIII, $\S 2$; U.S. CONST. amend. XIV, \& 2; U.S. CONST. amend. XV, \& 2; U.S. CoNST. amend. XVI, § 2; U.S. CONST. amend. XVIII, $\S 2$, repealed by U.S. CONST. amend. XXI; U.S. CONST. amend. XIX; U.S. CONST. amend. XXIII, $\$ 2$.

18. Indeed, there is a federal statute that does authorize the federal prosecution of state or local police in these circumstances-and, to be sure, it was adopted by Congress pursuant to Section 5. See 18 U.S.C. \& 242 (1994). 
Fourteenth Amendment, therefore, as if it did. In our view, that is a far better proposition than that which the opinion of the Supreme Court happens to reflect. We think ourselves as much entitled to measure the scope of the Fourteenth Amendment's coverage as are the members of the Supreme Court and, insofar as we deem it appropriate, by suitable legislation adopted for the purpose, we may render the Supreme Court's opinion altogether moot.

Moreover, there is a significant advantage to our understanding of the power vested in us by Section 5 of the Fourteenth Amendment. For it is only through our understanding that we can gain a rightful authority to override a much larger number of state laws, and further magnify federal authority over the states, as well as to override unacceptable decisions by the Supreme Court. Thus, our understanding of our superior role vis-àvis the Supreme Court, as vested in us pursuant to Section 5, is this: it enables us to review decisions of the Supreme Court as a super-Supreme Court and to say wherein the Supreme Court has erred in sustaining some state law or state practice as one that is not forbidden by Section 1 . When, moreover, a case arises that draws into question whether a given state practice does or does not violate the Fourteenth Amendment, and the Court says it does not, but we say it should nevertheless be deemed to do so, declaring our superseding and superior power to proceed in this fashion pursuant to Section 5, courts shall yield to our view and decide the case accordingly. For if the state statute is in conflict with our interpretation of the Fourteenth Amendment as we have presumed to declare it by law, the case shall be brought speedily to an end-decided as this Congress decrees shall be done. ${ }^{19}$

19. Compare this hypothetical language to strikingly parallel provisions in the RFRA. In $\S 2000 \mathrm{bb}(\mathrm{a})(5)$, Congress asserts its strong preference for a different First and Fourteenth Amendment standard-one it deems more suitable "for striking sensible balances between religious liberty and competing prior governmental interests"-than the Supreme Court has determined either amendment requires of a state. Compare RFRA $\S 2000 \mathrm{bb}-1$ (b) (protecting the free exercise of religion from governmental burden unless such restriction furthers a "compelling governmental interest" and "is the least restrictive means of furthering that . . . interest") with Employment Div. v. Smith, 494 U.S. 872, 878-79 (1990) (holding that a law whose objective is not to prohibit the free exercise of religion does not violate the First Amendment, even though the incidental effects of "a generally applicable and otherwise valid provision" do restrict free exercise). In the sections that follow, Congress then presumes to prohibit any state law that does not satisfy the standard it sets out, a standard that "substitutes" for the less restrictive test that the Court has declared to be, in the Court's view, all that the First and Fourteenth Amendments require. See RFRA §§ 2000bb-1, 2000bb-3; see also Sasnett v. Sullivan, 91 F.3d 1018, 1019, 1021 (7th Cir. 1996) (stating that "[The RFRA] thus seeks to return the 


\section{Put more succinctly, Congress reads Section 5 to say:}

Whatever Congress may declare to be inconsistent with any other clause in this amendment, any opinion of the Supreme Court or any other court notwithstanding, Congress may forbid to the States.

Of course Section 5 does not read this way or anything like it. Nor is it imaginable that were it recast in this fashion, it could have emerged from Congress as a serious proposal-whether in 1866 or today-and much less is it imaginable that it would have been ratified (or would now be ratified) by any state. ${ }^{20}$ It is a

courts ... to the approach they had taken before Smith. ... The motivation behind the [RFRA] was in fact disagreement with the Supreme Court's interpretation of the Constitution." (emphasis added)); Douglas Laycock \& Oliver S. Thomas, Interpreting the Religious Freedom Restoration Act, 73 TEX. L. REV. 209, 219 (1994) (declaring that the RFRA "is designed to restore ... rights that Congress believes should exist if the Constitution were properly interpreted" (emphasis added), which, of course, Laycock and Thomas think, in Smith, it was not, and that, to overrule Smith, Congress enacted the RFRA). The RFRA does not stand on a more modest claim (sometimes made) that it is merely an appropriate measure to prevent otherwise-difficult-to-prove violations of the First or Fourteenth Amendment (nor is it limited in any manner of speaking to any such kinds of cases, whatever one might fancy them to be). Cf. Douglas Laycock, RFRA, Congress, and the Ratchet, 56 MONT. L. REV. 145, 166 (1995); Flores v. City of Boeme, 73 F.3d 1352, 1359 (5th Cir. 1996), cert. granted, 117 S. Ct. 293 (U.S. Oct. 15, 1996) (No. 95-2074). See also infra text accompanying notes 50-62.

20. That such a proposal would not have passed in Congress, let alone have been ratified by the requisite number of states, is implicit in the rejection of H.R. 63, CoNG. GLOBE, 39th Cong., 1st Sess. 1033 (1866), an early draft of Section 1 introduced in February of 1866 by Representative Bingham of Ohio. See id. That proposed amendment itself did not presume to go nearly as far as the approach described above, yet even it was deemed unacceptable, even in Congress. Bingham's failed draft would merely have provided that:

The Congress shall have power to make all laws which shall be necessary and proper to secure to the citizens of each State all privileges and immunities of citizens in the several States, and to all persons in the several States equal protection in the rights of life, liberty, and property.

Id. at 1034 .

Two sorts of objections were raised by the opponents of this Congress-empowering proposal. First, the rights contained therein were not self-executing. Absent Congressional action, there would be nothing for the courts to apply. In other words, the amendment would be meaningless, except insofar as Congress provided affirmative legislation (which it could of course repeal at any time). Second, the proposed amendment at the same time would commit too much intrusive power to Congress by providing Congress with the power to oust state legislative jurisdiction to whatever extent it might presume to see fit. See, e.g., id. at 1063-66, 1094 (remarks of Rep. Hale (New York)); id. at 1095 (remarks of Rep. Hotchkiss (New York)); id. app. at 133-35 (remarks of Rep. Rogers (New Jersey)); $c f$. CONG. GLOBE, 42d Cong., 1st Sess. app. at 115-16 (1872) (remarks of Rep. Farnsworth (Illinois)). 
breathtaking assertion of bootstrap authority, an utter trivialization of federalism and of the Tenth Amendment.

The Tenth Amendment merely made explicit what was otherwise understood by the doctrine of enumerated powers-that Congress may make laws overriding state laws, but it may do so only to the extent it is granted express authority to do so, and not beyond. ${ }^{21}$ However, where a state law neither makes nor threatens an interference with any right each person has against a state under Section 1 of the Fourteenth Amendment (whether it be a right to a fair trial or, as here, a right to be free from searches and seizures not complying with the requirements of the Fourth Amendment-a matter each state concedes to be ultimately for the Supreme Court to decide despite its fervent position that the Court is mistaken), there is nothing in the grant of powers made to Congress (and assuredly nothing in Section 5 of the Fourteenth Amendment) authorizing Congress to instruct a state and its courts to ignore state law and instead to conduct judicial proceedings merely as Congress thinks more suitable.

Consideration of the proposal was postponed. The provision in H.R. 127, CoNG. GLOBE, 39th Cong., 1st Sess. 2265, 2286 (1866), that was subsequently to become Section 1 of the Fourteenth Amendment took, of course, a different form-Section 1 to be selfexecuting ("No state shall . . . .") and Section 5 simply allowing enforcement by Congress. See MichaEl KeNT Curtis, No STATE SHALl ABRIDGE 68-71, 128-29 (1986); ROBERT J. HARRIS, THE QUEST FOR EQUALITY 34-50 (1960); JOSEPH B. JAMES, THE FRAMING OF THE FOURTEENTH AMENDMENT 86, 189 (1956); Alexander M. Bickel, The Voting Rights Cases, 1966 SUP. CT. REv. 79, 97 [hereinafter Bickel, The Voting Rights Cases]; Alexander M. Bickel, The Original Understanding and the Segregation Decision, 69 HARV. L. REV. 1, 29-56 (1955); Jay S. Bybee, Taking Liberties with the First Amendment: Congress, Section 5, and the Religious Freedom Restoration Act, 48 VAND. L. REV. 1539, 1578-85, 1589-96, 1598, 1616-24 (1995); Michael P. Zuckert, Congressional Power Under the Fourteenth Amendment-The Original Understanding of Section 5, 3 CONST. CoMMENT. 123, $134-44$ (1986).

21. Indeed, a broader power in Congress to override state laws was unequivocally rejected during the Constitutional Convention. Well into the summer of 1787, Madison championed a proposal that Congress would have a "negative" on state laws. See, e.g., Letter from James Madison to George Washington (April 16, 1787), reprinted in II WRITINGS OF JAMES MADISON 346-49 (Gaillard Hunt ed., 1910). This national "veto" power residing in Congress was rejected on July 17, 1787, essentially for being too direct an interference with the legislative processes and prerogatives of the states. See II THE RECORDS OF THE FEDERAL CONVENTION OF 1787 27-28 (Max Farrand ed., 1937). The document that emerged from Philadelphia in September contained no trace of Madison's proposed congressional veto. 
B.

The case we have just examined is no different than were Congress alternatively, or additionally, to prescribe by federal law that "no state shall provide for the trial of any person charged with a violation of any of its criminal statutes by a jury consisting of fewer than twelve persons"-though the state law might itself provide for a jury of, say, six, or eight, rather than twelve. Must each state now comply with this act of Congress, alter its practice, accept the additional costs, and empanel only juries conforming to the congressional demand? There is no basis on which it should feel so obliged. The reason is exactly the same as in the case we just examined, namely, no authority is granted to Congress to demand any such condition as this, and certainly none at all under Section 5 of the Fourteenth Amendment.

Congress may believe that persons accused of various crimes ought to have all manner of extra, constitutionally unrequired, protections when subjected to criminal trial in state court-whether those protections be, for example, a twelve-person jury, ${ }^{22}$ or representation by "no fewer than two counsel" rather than one. ${ }^{23} \mathrm{~A}$ state may itself agree as a matter of policy, and may surely choose to so provide, by statute or in its constitution. But of course it need not. And, in not agreeing, it may make different provisions with respect to its criminal trials-with no suggestion that, in so doing, it in any way acts contrary to the Fourteenth Amendment.

And, indeed, the Supreme Court has expressly assured each state that this is so, declaring that the "due process of law" does not require twelve-person juries. Rather, it requires only that no

22. Or perhaps, for that matter, a fourteen-person jury. Note that the theory pursuant to which Congress claims power to "enforce" the Fourteenth Amendment's Due Process Clause is that Section 5 provides Congress not merely ample authority to ensure that every state meets its due process obligations (clearly the point of giving power to Congress, in Section 5, to "enforce" the article "by appropriate legislation")-but also authority to require the states to go beyond any and all measures deemed sufficient by the Supreme Court to bring the state into full compliance with the Due Process Clause. And if that is so, it seems merely to be a matter of congressional determination to say "how much more" the state must do. For example, if twelve is "better" due process than six, surely fourteen may be even "better" due process than twelve?

23. And, again, it may be able so to provide with respect to all federal criminal trials. With respect to prescribing the conditions of such purely federal trials, Congress is not limited merely to providing that they be conducted in a manner not inconsistent with the constitutional guarantees of the Fourth, Fifth, and Sixth Amendments. See supra text accompanying notes $12-13$. 
state criminal trial jury shall consist of fewer than six jurors. ${ }^{24}$ An act of Congress mandating that each state must nevertheless empanel larger juries to conduct felony trials-juries of no fewer than twelve persons - cannot be said to be legislation "authorized" by Section 5, for such legislation "enforces" nothing required by any clause in the Fourteenth Amendment according to the Supreme Court. ${ }^{25}$

What, then, does this act do? It overreaches congressional authority by presuming to mandate a policy which Congress might wish each state to adopt, but which each state obviously need not adopt in order to be in full compliance with the Fourteenth Amendment. It is, at best, a proposal-one that Congress may very well encourage, ${ }^{26}$ but one that it has no constitutional basis

24. See Ballew v. Georgia, 435 U.S. 223, 239 (1978).

25. By way of contrast, an act so doing-that is, an act of Congress actually (and merely) "enforcing" the Fourteenth Amendment due process right to trial by a jury of no fewer than six persons-would be an act that provided a secure means of overtuming any conviction obtained with a jury of fewer than that minimum number. And, to be sure, there is such an act. See, e.g., 28 U.S.C. \& 2241(c)(3) (1994) (federal habeas available in just this way). It might also be an act that provided for civil damages against the offending state personnel, or even against the state as such. See, e.g., 42 U.S.C. §§ 1983, 1985, 1986 (1994). Nor would the Eleventh Amendment bar Congress from providing that remedy directly against the state in federal court. See Fitzpatrick v. Bitzer, 427 U.S. 445, 456 (1976). It might be an act that imposed federal criminal sanctions against state officials who knowingly denied this Fourteenth Amendment right to an accused. See, e.g., 18 U.S.C. §§ 241, 242 (1994) (criminal sanctions applicable in such a case); Ex parte Virginia, 100 U.S. 339, $344-49$ (1879) (sustaining federal prosecution of state judge for excluding black citizens from petit and grand jury service). It could even include an act that provided for the immediate removal into federal court of any case wherein the accused would be unable to "enforce" that right. See, e.g., Strauder v. West Virginia, 100 U.S. 303, 311-12 (1879). The point of these examples is that Section 5 of the Fourteenth Amendment does, indeed, grant to Congress considerable authority to secure to each person every right the Supreme Court agrees is furnished by Section 1 . Indeed, it authorizes Congress to put federal armed forces at the disposal of the President to assure that federal court orders respecting the enforcement of the Fourteenth Amendment as declared by the Supreme Court shall not be obstructed or ignored by state governments-it authorizes enforcement with very real "teeth." See Cooper v. Aaron, 358 U.S. 1, 12 (1958) (mentioning, in a case upholding a federal court desegregation order, the President's use of federal troops to enforce that order (implicitly approved by Congress)).

26. To be sure, Congress may provide such "encouragement" by qualifying the availability of federal funds to assist states in the costs of operating their systems for administering justice-i.e., it might restrict eligibility for such assistance to states that provide for twelve-person juries. See Board of Educ. v. Mergens, 496 U.S. 226 (1990) (upholding the Equal Access Act, which prohibits public secondary schools receiving federal financial assistance from denying student organizations equal access to school facilities on the basis of the content, including religious content, of their speech). We do not pause to examine that possible use of the spending power "with strings attached." No such law or proposal 


\section{to mandate.}

The provisions of the Religious Freedom Restoration Act (RFRA) ${ }^{27}$ stand on exactly the same empty ground and are utterly indistinguishable. They are no different from the two examples we have now examined, or endless others we might just as easily propose. Perhaps it will be useful to provide just one more illustration, nonetheless, simply to make the point very clear.

\section{C.}

We turn, then, to a third example. Imagine a Congress, a "liberal" Congress-one much more tolerant of, or even supportive of, sexually explicit speech (including "obscenity") than the First Amendment requires it to be. ${ }^{28}$ If it wishes to embrace such a more tolerant policy, Congress may surely do so-it may assuredly relax or repeal such federal statutes (such as those governing the U.S. Post Office) as may currently restrict obscenity. ${ }^{29}$ Yet, although one readily concedes that this is so, nothing gives Congress any similar prerogative with respect to state and local laws-laws that are not of its creation and thus not similarly subject to its legislative preferences. It has no power, for example, to set aside a carefully and narrowly drawn anti-obscenity ordinance in Los Angeles, which ordinance meets every test the Supreme Court has repeatedly declared to be sufficient under the First and Fourteenth Amendments. ${ }^{30}$ Least of all could Congress presume to do so on the strength of any power confided to it by Section 5 of the Fourteenth Amendment (for example, by providing that no state law or

is before us, nor is the RFRA such a law.

27. 42 U.S.C. \& 2000bb (1994). See Appendix for the full text of the statute.

28. See Roth v. United States, 354 U.S. 476, 485 (1957) ("We hold that obscenity is not within the area of constitutionally protected speech . ....").

29. Note that in so doing, however, Congress would not be exercising a power to "enforce" the First Amendment. No such power is given to Congress; the First Amendment is not an empowering clause; it is a disabling clause (i.e., it disables Congress). Nor does the Necessary and Proper Clause apply, for that clause merely equips Congress to enact legislation suitable, in its view, to "carry into execution" such "powers" as are otherwise vested in it-and the First Amendment vests none in it (or in anyone else). For insightful discussions of this point, see Bybee, supra note 20, at 1555-57, and William T. Mayton, "Buying-Up Speech": Active Government and the Terms of the First and Fourteenth Amendments, 3 WM. \& MARY BILI OF RIGHTS J. 373, 386-405 (1994). Rather, in the example just provided, Congress would merely be exercising its discretion under the Post Office Clause. See U.S. CoNST. art. I, $\$ 8$, cl. 7.

30. See Miller v. California, 413 U.S. 15, 23-34 (1973) (discussing the First and Fourteenth Amendment constraints on state and local anti-obscenity laws). 
local ordinance presuming to regulate or restrict obscene material shall be deemed to be valid in any court).

To be sure, Congress need not be impressed with the Court's interpretations of the First Amendment," and so need not "conform" to them in its own legislation-it may permit freer circulation of obscene materials, as far as its own statutes are concerned, than the Supreme Court says it must allow. ${ }^{32}$ But it can scarcely claim to be "enforcing" any provision in the Fourteenth Amendment when it seeks to insulate local purveyors of obscene material from answering to constitutionally valid and unexceptional state and local laws fully sustained in the Supreme Court. Insofar as those state and local laws are consistent with the First and Fourteenth Amendments, the states owe no one an apology for enacting and fairly enforcing them. Nor is there any authority in Congress to forbid the states to do so, under pretense of "enforcing" the Fourteenth Amendment itself. ${ }^{33}$

31. For example, it may feel that the Court's interpretations are "too narrow," or "too rigid," or "insufficiently appreciative of the value of free speech."

32. For a useful review of such matters, see Paul Brest, Congress as Constitutional Decisionmaker and Its Power to Counter Judicial Doctrine, 21 GA. L. REV. 57, 61-68 (1986).

33. To override state laws forbidding the sale or possession of obscene materials the Court holds unprotected by the First and Fourteenth Amendments, Congress would need to rely on some other power than that vested by Section 5 . For example, it might rely on the power to "regulate commerce ... among the several states," as vested in Congress in Article I, pursuant to which it may protect trade in such publications it prefers to be freely circulated in the United States without interference by state laws. The RFRA makes no claim under the Commerce Clause, nor, given its reach-it presumes to reach literally every state law or practice-could it do so with any hope of being sustained. Cf. United States v. Lopez, 115 S. Ct. 1624, 1634 (1995) (holding that the Commerce Clause, although broad, is not so expansive to convert Congressional authority to a general police power of the sort retained by the states).

For a twice-useful comparison in this very regard, compare the Privacy Protection Act of 1980, 42 U.S.C. $\S 2000$ aa-6(f) (1994), with the RFRA. Just like the RFRA, the Privacy Protection Act was a congressional response to a Supreme Court decision, Zurcher v. Stanford Daily, 436 U.S. 547 (1978). See S. REP. No. 96-874, at 4 (1980), reprinted in 1980 U.S.C.C.A.N. 3950. It effectively displaces the decision, requiring the use of less intrusive subpoenas (rather than more physically intrusive search warrants) by police when material is sought of newspapers or other publishers, subject to certain exceptions (e.g., when "there is reason to believe ... immediate seizure . . . is necessary to prevent ... destruction" of the material). 42 U.S.C. $\$ 2000 \mathrm{aa}(\mathrm{b})(1)-(3)$. In contrast with the RFRA, however, the Privacy Protection Act is expressly tied to the Commerce Clause-specifically, it is solely applicable to work in preparation for newspapers, book publishers, and broadcast companies "in or affecting interstate or foreign commerce." Id. $\$ 2000 \mathrm{aa}$ (a), (b) (emphasis added). The RFRA makes no such pretense, of course, and also has no such limiting provision; again, it applies to every state law, whatever its sub- 
D.

The same is equally true when we turn, finally, to the Religious Freedom Restoration Act. ${ }^{34}$ A state, the Supreme Court has said (in Employment Division v. Smith), may excuse those who ingest various drugs incidental to some religious practice, ${ }^{35}$ but it is without constitutional obligation to make such an exception. ${ }^{36}$ This is equally true of Congress. Nothing in the First or Fourteenth Amendments compels the state (or Congress) to grant such an exception. In this respect, moreover, a state's neutral treatment of criminal drug use stands on the same permissible constitutional footing as its resolve to disallow obscene materials to be freely bought and sold, ${ }^{37}$ its use of six-person (rather than twelve-person) juries, ${ }^{38}$ or its policy to permit police searches of open fields. Whether a neighboring state, or the federal government, has a different policy on one or more of these matters-as each assuredly may $^{39}$-is for each to settle in respect to laws under its own re-

ject, whether or not connected to some kind of commerce. Whether the Privacy Protection Act is constitutional may depend on one's view of United States v. Lopez, $115 \mathrm{~S}$. Ct. 1624 (1995), but nothing more. It makes no claim of a supererogatory power in Congress of the sort asserted in the RFRA.

34. The Appendix to this Essay contains the full text of the RFRA.

35. The state may make such exception, that is, despite the Establishment Clause. And, in fact, immediately subsequent to the Court's decision in Smith, the Oregon legislature reconsidered and enacted just such an exception. See Or. Rev. Stat. Ann. \& 475.992(5) (Supp. 1996) (providing an affirmative defense for possession of peyote "used or ... intended for use ... [i]n connection with the good faith practice of a religious belief").

36. See Employment Div. v. Smith, 494 U.S. 872, 890 (1990).

37. It is just as clear that under Smith a state need not exempt religious vendors of criminally obscene materials from its criminal obscenity laws. (Though it may, if somehow so inclined.) See id.

38. Nor, under Smith, would the state need to empanel a jury of more than six merely to "accommodate" a defendant who adheres, in good faith, to a religion forbidding him, under pain of everlasting damnation, to be tried by a jury of fewer than twelve jurors. By way of contrast, under the RFRA this evidently would-or certainly might-be required of the state (since it would be easy enough, on such occasions, to empanel a jury of twelve and avoid a "substantial burden" on the accused). Our position here is the same as elsewhere, namely: if Congress, in its peculiar wisdom, wishes to provide for highly "religion-specific accommodations" in federal trials, perhaps it may do so as a matter of policy (despite what should strike many as an inappropriate form of religion-favoring inconsistent with the Establishment Clause). But, however that may be, Congress has no equivalent authority to impose such a policy on any state-not pursuant to anything in Article I, nor anything in Article III, nor anything in Section 5 of the Fourteenth Amendment itself.

39. See New State Ice Co. v. Liebmann, 285 U.S. 262, 311 (1932) (Brandeis, J., dissenting) ("It is one of the happy incidents of the federal system that a single courageous 
spective authority, on such policy terms as it deems best for itself. ${ }^{40}$ They have command of their own policies, nothing more. ${ }^{41}$

Congress, of course, does nothing wrong when it merely enacts legislation which it believes, in good faith, to be appropriate to enforce the constitutional obligations of each state as set out in Section 1 of the Fourteenth Amendment. Frequently Congress may have no choice other than to move ahead with legislation--matters may seem to call for positive measures of enforcement in a time or in a setting where there remains genuine uncertainty concerning the scope of the obligations imposed by Section 1 . No one contends that Congress must somehow "wait" for the Supreme Court's determination of the issue. Nevertheless, whenever Congress so conducts itself, it is necessarily for the Court eventually to say, once that Congressional assertion respecting each state's obligation has been challenged (as eventually it may be), whether Congress has got the matter right, or got it quite wrong. ${ }^{42}$ And here, unless

State may, if its citizens choose, serve as a laboratory; and try novel social and economic experiments without risk to the rest of the country.").

40. Indeed, a state may well have provisions in its own constitution that are substantially more restrictive of state action than anything compelled by Congress or by the U.S. Constitution. Compare, e.g., State v. Scott, 593 N.E.2d 1328, 1337-38 (N.Y. 1992) (finding that Article I, Section 12 of the New York Constitution protects private lands, clearly fenced and posted against trespassers, from searches), with Oliver v. United States, 466 U.S. 170, 184 (1984) (finding that neither the Fourth nor Fourteenth Amendment mandates this treatment by New York). See also California v. Greenwood, 486 U.S. 35, 43 (1988) ("Individual States may surely construe their own constitutions as imposing more stringent constraints on police conduct than does the Federal Constitution."); William W. Van Alstyne, "Thirty Pieces of Silver" For the Rights of Your People: Irresistible Offers Reconsidered as a Matter of State Constitutional Law, 16 HARV. J.L. \& PUB. POL'Y 303, 304-05 (1993) (citing cases and state constitutional provisions securing other rights).

41. See New York v. United States, 505 U.S. 144, 162 (1992), which states that "the Constitution has never been understood to confer upon Congress the ability to require the States to govern according to Congress' instructions." Nothing in the Fourteenth Amendment takes any exception to this dictum. Section 5 empowers Congress to secure scrupulous compliance with the limitations on the states imposed by Section 1, including preventive and remedial legislation, but nothing more (i.e., it does not empower Congress to require the States to govern according to Congress' direction, as the RFRA commands).

42. It is as much the case here, as it was in Marbury v. Madison, that: "The powers of the legislature are defined and limited .... To what purpose are powers limited, and to what purpose is that limitation committed to writing, if these limits may, at any time, be passed by those intended to be restrained?" 5 U.S. (1 Cranch) 137, 176 (1803), applied in Oregon v. Mitchell, 400 U.S. 112, 118, 124-31 (1970) (striking federal statute that viewed as a violation of equal protection state laws not permitting 18-year-olds to vote in state elections); Civil Rights Cases, 109 U.S. 3, 25 (1883) (invalidating act of Congress that presumed to reach acts through Section 5 that the Court held not reached by Sec- 
the Court is itself willing already to concede error in its own decision in Employment Division v. Smith, ${ }^{43}$ it must hold that Congress has gotten the matter quite wrong in fact.

Indeed, unless the Court is prepared to abandon Smith, the case is not even close. The Court has declared that the Fourteenth Amendment steers a fine course between the Free Exercise and Establishment Clauses-that is, it permits, but does not require, a state to provide religion-favoring exemptions from the burden of compliance with its general laws. Nevertheless, Congress insists quite plainly that a state must do so. Here we do not have a situation where Congress is excused by any original uncertainty. Congress did not lack for any guiding decision from the Court. Rather, it knew the Court's decision. It simply did not like that decision, and, not liking it, moved quite literally to substitute as "law" the view of the dissent in the case. Even those justices who dissented in Smith should be reluctant to accept this view of congressional power under Section 5-power to approve what a dissent may say (as to the proper reach of the Fourteenth Amendment) and, by congressional fiat, in the mere verbal cellophane of Section 5, elevate it by congressional anointment as the law of the land.

tion 1). For recent decisions of the Supreme Court confirming its continuing commitment to take constitutional federalism seriously whenever suitably raised, see Seminole Tribe $v$. Florida, 116 S. Ct. 1114, 1119 (1996) (holding that "notwithstanding Congress' clear intent to abrogate the States' sovereign immunity, the Indian Commerce Clause does not grant Congress that power"), United States v. Lopez, 115 S. Ct. 1624, 1626 (1995) (holding that the Gun-Free School Zones Act of 1990 exceeded Congress' authority to regulate interstate commerce), and New York v. United States, 505 U.S. 144, 149 (1992) (holding that "while Congress has substantial power under the Constitution to encourage the States to provide for the disposal of the radioactive waste generated within their borders, the Constitution does not confer upon Congress the ability simply to compel the States to do so").

43. 494 U.S. 872 (1990). The possibility is a substantial one. The decision was five-tofour, and Justice Souter has since disclaimed any willingness to invest Smith with any courtesy of stare decisis, see Church of Lukumi Babalu Aye v. Hialeah, 508 U.S. 520, 559 (1993) (Souter, J., concurring). Ironically, however, the effrontery of the RFRA should make the prospect of such an overruling less, rather than more, likely. For the Court to overrule Smith in these circumstances would itself suggest a form of judicial truckling to Congress wholly unworthy of the Court. See Planned Parenthood v. Casey, 505 U.S. 833, 845-46 (1992) (declining the government's invitation to overrule Roe v. Wade, 410 U.S. 113 (1973), out of concern for "principles of institutional integrity and the rule of stare decisis"). 
II.

A.

The flaw in the RFRA is not so simple as "Congress has instructed the Supreme Court how to interpret the Free Exercise Clause of the First Amendment." ${ }^{44}$ Congress has not done this; the Act's defenders are quite correct on this point, ${ }^{45}$ and the Act cannot be faulted on this particular ground. ${ }^{46}$ This is so, however,

44. Hamilton v. Schriro, 74 F.3d 1545, 1566 (8th Cir.) (McMillian, J., dissenting), cert. denied, 117 S. Ct. 193 (1996); see also In re Young, 82 F.3d 1407, 1421 n.1 (8th Cir. 1996) (Bogue, J., dissenting) ("Having reviewed and studied [Judge McMillian's] thorough opinion in Hamilton, I am inclined to agree with his position."), petition for cert. filed, 65 U.S.L.W. 3205 (U.S. Sept. 19, 1996) (No. 96-437); State v. Miller, 538 N.W.2d 573, 579 (Wis. Ct. App. 1995) (Sundby, J., dissenting) ("I do not accept that Congress may compel the United States Supreme Court to interpret the Free Exercise Clause of the First Amendment as Congress believes it should be interpreted."), aff d, 549 N.W.2d 235 (Wis. 1996); cf. Eugene Gressman \& Angela C. Carmella, The RFRA Revision of the Free Exercise Clause, 57 OHno ST. L.J. 65, 121 (1996) ("[The] RFRA is a congressional arrow aimed directly at the heart of the independent judicial function of constitutional interpretation."); Christopher L. Eisgruber \& Lawrence G. Sager, Why The Religious Freedom Restoration Act is Unconstitutional, 69 N.Y.U. L. REv. 437, 469, 473 (1994) ("Common sense suggests that [the] RFRA is a congressional effort to overrule the Supreme Court on a point of constitutional interpretation. ... That is what RFRA's supporters wanted, and that is what they got.").

45. See, e.g., Bonnie I. Robin-Vergeer, Disposing of the Red Herrings: A Defense of the Religious Freedom Restoration Act, 69 S. CAL. L. REV. 589, 612-26 (1996) (and see the sources cited therein).

46. The problem with the RFRA is also not that it somehow unconstitutionally empowers the courts "to pass on religious questions," an objection raised recently by Justice Mosk of the California Supreme Court. See Smith v. Fair Employment \& Hous. Comm'n, 913 P.2d 909, 931 (Cal. 1996) (Mosk, J., concurring) (claiming that Congress, by unconstitutionally requiring the judiciary to address religious questions through RFRA, has violated separation of powers), petition for cert. filed, 65 U.S.L.W. 3034 (U.S. July 8, 1996) (No. 96-31) [unrelated to the Supreme Court's decision in Employment Division $v$. Smith]; see also In re Tessier, 190 B.R. 396, 406-07 (Bankr. D. Mont. 1995) (alleging unconstitutionality of the RFRA on grounds that it incorporates a standard for deciding religious questions that the Court had previously rejected and usurps the judiciary's authority to determine the propriety of its jurisdiction); Joanne C. Brant, Taking the Supreme Court at Its Word: The Implications of RFRA and Separation of Powers, 56 MONT. L. REV. 5, 6 (1995) (arguing that because the Supreme Court has refused to balance religious liberties against neutral government regulations, Congress cannot override that decision through ordinary legislation); Scott C. Idleman, The Religious Freedom Restoration Act: Pushing the Limits of Legislative Power, 73 TEX. L. REv. 247, 273 (1994) (arguing that after Smith, the RFRA's requirement that the courts inquire into the substantiality of a burden on free exercise may be, in fact, unconstitutional). A variation of the argument appears in Eisgruber \& Sager, supra note 44, at 445-52 (questioning the ability of courts to work with consistency or predictability within the entanglements of the Sherbert-Yoder test Congress requires them to use). 
simply because Congress has not presumed to instruct any court directly on how to interpret, or judicially apply, anything in the Constitution. In the RFRA, Congress has not obtusely declared that:

In every case arising under the Free Exercise Clause of the First Amendment, the court shall construe that amendment to forbid any law substantially burdening a religious belief or religiously motivated act or practice, unless ... [etc.]. ${ }^{47}$

There are such cases, to be sure. That is, there are cases where resolution of the legal dispute would plunge a court into matters more appropriately deemed internal ecclesiastical disputes-matters with respect to which the Court has declared secular authority may not presume to take sides. See, e.g., EEOC v. Catholic Univ. of Am., 83 F.3d 455, 466-67 (D.C. Cir. 1996); see also WILliaM W. VAN ALSTYNE, FIRST AMENDMENT CASES AND MATERIALS 1126-56 (2d ed. 1995) (presenting cases and discussion on the issue of government neutrality). But the RFRA would not create such a situation. And Smith was not decided on the basis that requiring a court to decide whether a state law impinges in some "substantial way" on a person's "religious" practices or beliefs would per se unconstitutionally entangle that court in deciding essentially religious questions. It does not. As the Court itself has often enough observed, it is perfectly possible for there to be a "religion of one"-that is, an individual's wholly personal "religion" which is nevertheless one's religion, though no ordinary church or religion would recognize it. See, e.g., United States v. Ballard, 322 U.S. 78, 86-88 (1994); see also United States v. Seeger, 380 U.S. 163, 185-88 (1965). Accordingly, requiring that a claimant show in what way his religiously impelled practices-whatever they may be-would be substantially (rather than insubstantially) burdened by the law in question simply does not per se entangle courts in unravelling strands of religious doctrine, or in taking sides in ecclesiastical disputes.

While understandable, Justice Mosk's view is nonetheless incorrect and involves a misreading of the Supreme Court's decision in Smith. Indeed, Mosk's concem cannot be accurate, since the Smith decision itself permits legislatures to exempt religious persons from complying with laws of general application-notwithstanding the Establishment Clause-and holds merely that nothing in the Free Exercise Clause compels legislatures to do so. See Smith, 494 U.S. at 878-80, 890. Obviously, however, if a legislature were to do so, any person claiming the benefit of the statutory exemption would have to demonstrate his eligibility. In other words, the Smith decision itself contemplates and permits legislation that would draw the courts into the determination of the bona fides of individual religious claims.

47. That the RFRA does not operate in this fashion is illustrated by Smith v. Fair Employment \& Housing Commission, 913 P.2d 909 (Cal. 1996), petition for cert. filed, 65 U.S.L.W. 3034 (U.S. July 8, 1996) (No. 96-31). In that case, a religiously anguished landlord sought relief from a state anti-discrimination statute exposing her to damages for refusing to rent to unmarried cohabiting couples. (To do so, according to her good faith religious beliefs, would impermissibly implicate her in committing a sin-that is, facilitating their immoral living arrangement.) She presented two distinct federal claims, using 42 U.S.C. $\S 1983$ as the vehicle for both. The first claim was that the statute as applied to her was invalid under the First Amendment, as applied through the Fourteenth Amendment. Applying solely the Supreme Court's First Amendment standards as provided in Smith by Justice Scalia (writing for the Court), the state supreme court rejected her claim. See id. at 918-21. The issue was deemed easy. The impugned state law was neutral on its face and was of general application, and there was no suggestion that it had 
The RFRA is, rather, closer in its design to the statute at issue in United States v. Klein. ${ }^{48}$ In that 1870 statute, Congress instructed the Court as to the legal effect of a presidential pardon. ${ }^{49}$ The statute thus breached separation of powers both with respect to the president's pardon power (i.e., nullifying it) and with respect to the judicial power (i.e., dictating the legal effect of a presidential pardon). With the RFRA, the directive is to dictate the legal effect courts are to give to any party's free exercise claim-directing the court to give it the legal effect appropriate in Congress' view (as stipulated in the statute), contrary to the judicial understanding of the Free Exercise Clause..$^{50}$ The RFRA

been adopted out of any religious animus. Nor was there any additional constitutional claim entwined with her religious claim. Thus all the criteria of Smith were readily met. That having been decided, the court then separately examined her claim based on the different (and more stringent) provisions of the RFRA, pursuant to which it narrowly concluded that the act was valid as applied. See id. at 921-29.

For another example, see Hamilton v. Schriro, 74 F.3d 1545 (8th Cir.), cert. denied, 117 S. Ct. 193 (1996). Here, a Native American state prisoner challenged a prison regulation restricting hair length and the prison's lack of a suitable sweat lodge. Using 42 U.S.C. $\S 1983$, the prisoner alleged a claim under the First Amendment Free Exercise Clause and a claim under the RFRA. Although the majority denied both claims, the dissent made it plain that-were he to find the RFRA constitutional-he would permit the RFRA challenge (but not the Free Exercise challenge) of the hair regulation to proceed. Id. at 1557 (McMillian, J., dissenting).

Each of these cases is highly instructive in a different way, however, for each also indicates very well the intended effect of the RFRA. What is that "intended effect"? It is that while the RFRA does not affect how a court adjudicates the First Amendment claim, it takes steps to ensure that any such adjudication will no longer matter. Nothing need turn on it-the very purpose of the Act is to ensure that this will be so, to marginalize any such determination by the court, and to do so, moreover, to the point of making it a virtual irrelevancy (in effect, to reduce it to mere trash). Each of the cases just noted illustrates the point perfectly well, as do the cases cited infra at note 51 .

48. 80 U.S. (13 Wall.) 128 (1871).

49. Briefly, the problem was this. Congress had provided for the recovery of private property captured by the United States during the Civil War, provided the claimant proved that "he [had] never given any aid or comfort to the ... rebellion." Act of March 12,1863 , ch. $120, \S 3,12$ Stat. 820, 820. The Supreme Court had then affirmed judgments against the United States for such property, based in part on presidential pardons. See Klein, 80 U.S. (13 Wall.) at 182-83 (citing as an example United States $v$. Padleford, 76 U.S. (9 Wall.) 531 (1870)). Subsequently, in 1870, Congress dictated that "any pardon ... granted by the President ... shall be taken and deemed ... conclusive evidence that such person did take part in and give aid and comfort to the ... rebellion." Act of July 12,1870 , ch. 251, 16 Stat. 230, 235. This latter statute came before the Supreme Court in Klein.

50. Judge Smalkin caught the distinction, as well as the connection, between the RFRA and the statute at issue in Klein in his recent opinion, Keeler v. Mayor of Cumberland, 928 F. Supp. 591, 604 (D. Md. 1996) (holding the RFRA beyond the power vested in Congress by Section 5 of the Fourteenth Amendment). Judge Smalkin stated: 
[The] RFRA itself forthrightly declares that its purpose is to restore the compelling interest test as the rule of decision in cases implicating the First Amendment. ... [The] RFRA violates the constitutional separation of powers by requiring the courts to employ a standard of judicial review for First Amendment cases which has been expressly rejected by the Supreme Court. . . . This [court] is aware of no other statute by which Congress resurrected a judiciallyrejected standard of judicial review for an entire class of constitutional cases.

Id. at 598-604. By the substantive terms of the RFRA, in Judge Smalkin's view, courts are thus instructed to disregard the Court's view of the First Amendment and to apply Congress' view instead (i.e., the view it enacted in the RFRA). And, in this sense, the observations of Gressman, Carmella, Eisgruber, and Sager, see supra note 44, are also quite right. Paul Brest presciently anticipated just this kind of act a full decade ago. See Brest, supra note 32, at 76 ("What are the possible consequences if Congress does attempt to contradict judicial doctrine? First, the Court might simply defer to Congress' interpretation; this would, of course, require overruling or at least significantly modifying Marbury.") (footnote omitted).

By his reference to an "entire class of constitutional cases," see Keeler, 928 F. Supp. at 604, Judge Smalkin also distinguished, quite appropriately, the reach of the reasoning in Katzenbach v. Morgan, 384 U.S. 641 (1966). The reasoning (such as it is) sustaining the Morgan statute is readily distinguishable. Judge Smalkin's observation was that in cases of the Morgan genus, Congress relied on a "specially informed legislative competence"-not competence with respect to the "proper meaning" of the constitutional provision in question, but rather a "special competence" (such as it may be) to examine specific problematic areas. Keeler, 928 F. Supp. at 602-03 (quoting Morgan, 384 U.S. at 656). According to this paradigm, Congress would (a) take a hard look into a particular subject (e.g., literacy tests, race, and voting rights); (b) take a measure of the area as it deems warranted (e.g., review where such tests are given, how they tend to be applied, the extent to which they may lend themselves to improper application, the extent to which that has in fact occurred, etc.); (c) measure the adequacy of current means to address the problem(s); and, when Congress deems it appropriate to do so, (d) propose by statute a suitable additional measure convincing to Congress as a necessary and proper one-a statute to be respected insofar as courts can see a "reasonable basis" for it, given Congress' findings, such as they are. Legitimate Morgan cases, such as they are, are of this retail kind. See, e.g., City of Rome v. United States, 446 U.S. 156, 176-77 (1980); Fullilove v. Klutznick, 448 U.S. 448, 476-78 (1980). Even the statute at issue in Oregon v. Mitchell, 400 U.S. 112 (1970), retained more (though not enough) of this character than anything akin to the RFRA. See Brest, supra note 32, at 72-78.

To model another act of Congress so as to more nearly resemble the RFRA, in the very sense that Judge Smalkin had in mind (in correctly concluding that the RFRA dictates the substance of judicial review in all cases colorably asserting a Free Exercise claim), one would need an act declaring nothing in reference to any specific "problemarea" of equal protection cases. It would be an act simply declaring a very strong view of what the Equal Protection Clause forbids-for example, an act providing that: "No act or action of any kind by any state or local government substantially more burdensome to some persons within the jurisdiction of the state than to other persons within the same state, shall be adopted or applied by any state." The statute, if it were truly akin to the RFRA in both purpose and effect, would further declare that: "It is the express purpose of this act to make it of no legal consequence (and thus no defense to the state) that nothing the state has done or failed to do is inconsistent with any provision in the Fourteenth Amendment merely according to the Supreme Court." 
means (and declares that it means) to make the alleged "right" of the complaining party carry more by way of entitlement than the Court has declared the Constitution provides. It does not put too fine a point on the matter to say that the RFRA is meant to make the lack of a meritorious First Amendment claim (an "unmeritorious" claim, in the Supreme Court's view) utterly irrelevant. ${ }^{51}$

The RFRA thus presupposes that the courts will reject the First Amendment claim or defense as "without merit" so long as Smith remains intact. ${ }^{52}$ (Indeed, it is only in such a circumstance that the RFRA has any work of its own.) Yet for all that (and herein is the anomaly), it purports still to be an act providing for the mere "enforcement" of the First Amendment ${ }^{53}$-even while seeking to make the Court's view of the First Amendment irrelevant insofar as the Court's view (of what the amendment does and

Moreover, contrary to Judge Posner's suggestion in Sasnett v. Sullivan, it is plainly not the design of the RFRA merely "to make the formal right of religious freedom of persons who lack political power in individual states ... a meaningful right." 91 F.3d 1018, 1021-22 (7th Cir. 1996). Rather, it is (as Judge Posner conceded elsewhere in the same opinion, see id. at 1020-21) the express design of the RFRA-a design it presumes exactly to fulfill-to assert that Congress' view, not the Supreme Court's view, of what varieties of state laws shall not be deemed consistent with the First Amendment shall control-indeed that religious exemption entitlements shall generally be fumished in every state, across the board, under every law, absent some sufficient excuse the state must be prepared to prove by the standards Congress presumed to reenact in the RFRA.

51. Which is precisely what the Act does. See, e.g., cases and discussion supra notes 47 and 50; see also Jolly v. Coughlin, 76 F.3d 468, 475 (2d Cir. 1996) (finding likelihood of success on the merits in Rastafarian inmate's RFRA challenge to "medical keeplock" (confinement) for failure to submit to tuberculosis test; the court did not evaluate his First Amendment free exercise claim, but did note its lesser standard); Hicks v. Garner, 69 F.3d 22, 25-26 (5th Cir. 1995) (permitting Rastafarian inmate to proceed with RFRA, but not First Amendment free exercise, challenge to prison hair length and beard regulations).

52. In this respect, moreover, it is very much like the statute involved in Klein. See supra notes $48-49$ and accompanying text. In that instance, too, Congress presupposed that without its instruction respecting the judicial use to be made of the pardon Klein relied upon, the Court was likely to treat that pardon exactly in the manner Klein proposed. Congress sought to "veto" that presumed treatment, by its directive to the Court. See id.

53. Or, rather, the "enforcement" of the Fourteenth Amendment-specifically, the "liberty due process" feature that is deemed to apply the First Amendment Free Exercise Clause co-equally to the states. See, e.g., Cantwell v. Connecticut, 310 U.S. 296, 303-04 (1940). The RFRA's theory is that Congress can make water run uphill, by finding "rights" in the Fourteenth Amendment (namely, special entitlements to exemptions from laws of general application) notwithstanding the Supreme Court's view that no rights of this exceptional sort are encompassed by the First Amendment. 
does not prohibit) may be inconsistent with its own. ${ }^{54}$ In turn, that the RFRA "just happens" to select the standards it directs all courts to apply from previous (but now discarded) views of the Supreme Court (views the Court once thought, but no longer thinks, appropriate as a matter of First Amendment law)-rather than from some other source-is made irrelevant under the Act. The Act enacts what it enacts. But it is not irrelevant under the Constitution insofar as the question under the Constitution is where Congress got the authority to substitute these standards, such that they now become "the supreme law of the land."

We know what Congress claims. On the face of the RFRA itself, Congress claims a power under Section 5 of the Fourteenth Amendment to pick and choose among various Supreme Court justices and from various past opinions respecting the extent to which states are or are not limited by the First and Fourteenth Amendments. And it claims that Section 5 of the Fourteenth Amendment empowers it to elevate a dissent's view into supreme law, by statute, when Congress adds its votes to those of the dis-

54. See supra notes $19,47,50$, and 51 and accompanying text. It is just this uniquely sweeping and aggressive feature of the Act that has, quite understandably, led observers such as Brest, Eisgruber, Sager, Gressman, and Carmella, see supra notes 32 and 44, to see it as an attack on Marbury v. Madison-that is, insofar as it claims a power in Congress to set aside constitutional interpretations by the courts when such interpretations are not acceptable to Congress. And in that sense, they are quite right. See RFRA $\S 2000 \mathrm{bb}(\mathrm{b})(1)$ (reporting that the purpose of the Act is to make the view of the Supreme Court respecting what the First Amendment does and does not do as, hereafter, to count for nothing insofar as it differs from Congress' view). That this is the intended effect is quite clear. See Laycock \& Thomas, supra note 19, at 219 (quite unembarrassedly describing the RFRA as meant to be "a replacement for the Free Exercise Clause" and, as a replacement, "as universal as the Free Exercise Clause") (emphasis added). An act that is a "replacement" for a provision in the Constitution (and "as universal" as the provision it "replaces"), however, can hardiy be described in the same breath as merely an "enforcement" of the very thing it replaces, or so one may quite properly-perhaps even tartly-suggest. And there can be no doubt that the Act was intended as that replacement.

The Act thus does not stand merely on a claim that it is simply an appropriate measure to prevent otherwise-difficult-to-prove violations of the First or Fourteenth Amendment. Cf. Laycock, supra note 19, at 146; Sasnett v. Sullivan, 91 F.3d 1018, 1019 (7th Cir. 1996); Flores v. City of Boeme, Tex., 73 F.3d 1352, 1361 (5th Cir.), cert. granted, 117 S. Ct. 293 (Oct. 15, 1996) (No. 95-2074). It stands, rather, on a blunt claim of authority in Congress to legislate an interpretation of the First (and Fourteenth) Amendment, an interpretation that Congress prefers to the Supreme Court's, and authority to require that interpretation to be applied in all courts and with respect to all free exercise cases. 
senting justices ${ }^{55}$ and thus empowers it to determine how the states are to be governed. ${ }^{56}$

But if, indeed, Congress has this special power, there is little reason to think that it must find the standards it enacts in even some past (discarded) or some current (dissenting) opinion of the Supreme Court, rather than, say, finding them in some well-written article by Douglas Laycock, ${ }^{57}$ or in a column by George Will or

55. Compare the following version of the RFRA:

In any case where the free exercise claim would fail under the First Amendment according to the majority in Smith, but not fail under the First Amendment according to the dissent in Smith, the court shall-according to our instruction-decide the case before it in the manner directed by the dissent in Smith, namely, in the following manner [etc.].

In what way, if any, does this differ from the RFRA? Not at all. Indeed, Congress did enact this statute, merely rephrased-this is the RFRA.

56. Although, note, not how Congress itself is to be governed. For the RFRA provides an exemption from its own provisions for any act of Congress that expressly exempts itself ( $\$ 2000 \mathrm{bb}-3(\mathrm{~b})$ of the Act so provides), no such privilege, however, being available by the terms of the Act to any state. This feature of the RFRA is merely further indicative of its anomalous and spurious claims. On the one hand, the statute purports to do no more than "enforce" a clause (the Free Exercise Clause of the First Amendment) made merely as binding on the states by force of the Fourteenth Amendment as it is already on Congress. On the other hand, the statute expressly provides that Congress may pass legislation and provide that the legislation applies uniformly and unexceptionally to all persons (i.e., may exempt itself from the strictures of the RFRA)-such that no court may deem the legislation inapplicable merely because it happens to burden certain religious practices, whether or not it serves any compelling interest. At the same time, of course, Congress makes no claim at all that it can thereby also exempt itself from the Free Exercise Clause as interpreted, understood, and applied by the Supreme Court.

So, for example, Congress may enact any drug control laws it thinks suitable (merely pursuant to the Commerce Clause and the Necessary and Proper Clause), declare the RFRA inapplicable for such reasons as are satisfactory to itself, and count on courts never to subject the law to the standards of the RFRA (which are not, therefore, First Amendment standards after all)-with complete and correct confidence that the law will not be deemed to offend the First Amendment so long as it meets the standards of Smith and so long as Smith itself commands a majority in the Supreme Court. But Congress presumes to maintain that no state law, however neutral (i.e., no matter how similar to its own) could be equally valid, no matter how well it likewise complies with Smith. For, again, so far as the states are concerned, Congress has declared that the Court's view of the First Amendment is not controlling; rather, its own view, "re-enacting" the Sherbert-Yoder test, shall be the First Amendment governing the states-albeit not equally governing itself to the extent it chooses not to be so governed. The coy provisions of the RFRA-with its express, carefully built-in, self-exemption clause-merely further expose the straw of its own construction. It is as if Section 5 empowered Congress to enforce a version of the First Amendment to which the states must do homage, though Congress itself need pay no similar homage except just so far as it feels inclined.

57. See Douglas Laycock, The Remnants of Free Exercise, 1990 SUP. CT. REV. 1; see also Brant, supra note 46 , at 7 . Brant states: 
Art Buchwald. ${ }^{58}$ The source of Congress' inspiration is really of little moment, for nothing turns on it: the challenge, in the sense of which Justice Jackson wrote in Brown v. Allen, ${ }^{59}$ is the same. Was Congress, in a word, ever put in charge of "overruling" the Supreme Court, and given power to "reverse"60 the Court's decisions, expediently legislating a dissenting opinion into "law" thereafter to govern, until such time as Congress might experience some change of mind? ${ }^{61}$ It seems seriously doubtful that this can be so. $^{62}$ Rather, a more nearly accurate description respecting Congress' enforcement authority in respect to the prohibitory clauses of the Fourteenth Amendment is very likely this:

When recognized state violations of federal constitutional standards have occurred, Congress is of course empowered by $\S 5$ to take appropriate remedial measures to redress and prevent the wrongs. But it is a judicial question whether the condition with which Congress has thus sought to deal is in truth an infringement of the Constitution, something that is the necessary prerequisite to bringing the $\S 5$ power into play at all..$^{63}$

The new House Bill 2797 [which eventually became the RFRA] contained a section entitled "Congressional Findings and Declaration of Purposes," consisting of five findings of fact and two definitive statements of purpose [retained in final version of the RFRA]. No basis for these factual findings appears in the legislative record. Rather, they appear to be drawn from the remarks of one senator and an academic witness [Laycock] who submitted several letters and testified in support of the Act.

Id. (footnotes omitted) (emphasis added).

58. Indeed, Congress might just as readily have gotten its standards from something that Art Buchwald, George Will, or William Safire sparked off, in a merely complaining or humorous (or merely mischievous) column on "What Ought to Be Given to Religious People (Though Not Equally to Anyone Else) By Way of Exemption from Otherwise Valid Laws." In a straightforward understanding of its provisions, of course, this is not merely what the RFRA means to do; rather, Congress meant to dictate what the Fourteenth Amendment shall be deemed to require and what all states must therefore do-whether otherwise inclined or not, and though the Supreme Court has declared this is not required by any provision in the Constitution.

59. See supra text accompanying note 2 ("if there were a super-Supreme Court . . . .") (emphasis added).

60. See supra text accompanying note 3 (President Clinton's statement at the signing of the RFRA) ("[T]his act reverses the Supreme Court's decision . . . .").

61. That is, until a later Congress decides that perhaps the majority in Smith actually got the matter right, after all, and so "enacts" that view into law instead. (Congress' view of its authority pursuant to Section 5 implicitly claims authority to "overrule" itself, of course, as well as to "overrule" the Supreme Court.)

62. See supra note 20 and accompanying text.

63. Katzenbach v. Morgan, 384 U.S. 641, 666 (1966) (Harlan, J., dissenting) (citation omitted). Justice Rehnquist made a similar point in his dissent in City of Rome v. United States: 
B.

The polar opposite position, on this quintessential separationof-powers question, is laid bare in the view offered by Professor William Cohen. It is that whatever the state would be free to do to relax its law, Congress can do "for it" instead. That is, Congress may impose such rules to limit the states as Congress thinks best, and go as far as the most permissive state could, as a simple domestic policy choice. ${ }^{64}$

The Cohen position, however, ultimately frankly detaches itself from any effective pretense of having any real connection at all with Section 5 of the Fourteenth Amendment. In fact, it stands or falls on the utter abandonment of federalism review by the Supreme Court. ${ }^{65}$ It is wholly of a commonplace piece with the Wechsler-Choper federalism thesis, effectively declaring that the courts should simply take the view that the Constitution leaves it to Congress to determine the extent to which the states retain any authority to legislate in any way Congress may or may not wish them to, regardless of subject matter. ${ }^{66}$ The Cohen thesis also

If the enforcement power is construed as a "remedial" grant of authority, it is this Court's duty to ensure that a challenged congressional Act does no more than "enforce" the limitations on state power established in the Fourteenth ... Amendment $\square$. Marbury v. Madison.

....

... [I]n order to invoke a remedy, there must be a wrong-and under a remedial construction of congressional power to enforce the Fourteenth .... Amendment], that wrong must amount to a constitutional violation. Only when the wrong is identified can the appropriateness of the remedy be measured.

446 U.S. 156, 211, 213 (1980) (Rehnquist, J., dissenting) (emphasis added) (citation omitted).

64. See William Cohen, Congressional Power to Interpret Due Process and Equal Protection, 27 STAN. L. REV. 603, 614 (1975). Cohen writes:

[A] congressional judgment resolving at the national level an issue that could-without constitutional objection-be decided in the same way at the state level, ought normally to be binding on the courts, since Congress presumably reflects a balance between both national and state interests and hence is better able to adjust such conflicts.

Id; see also LAURENCE H. TRIBE, AMERICAN CONSTTTUTIONAL LAW $\S 5-14$, at 347-48 (2d ed. 1988) (summarizing this position).

65. Professor Cohen candidly conceded (in attempting to make some broad categorical sense of Katzenbach v. Morgan as he tried, conscientiously, to do) that his position is also inconsistent with the Court's decision in Oregon v. Mitchell. See Cohen, supra note 64 , at $616-17$ ("One difficulty with the liberty-federalism theory is that it will not distinguish . . . Katzenbach v. Morgan and Oregon v. Mitchell.")

66. The notion, in sum, is that the states were never to receive any judicial protection under the Constitution (i.e., protection through the courts)-that they were solely to 
breaks with rationalizing the act of Congress as a mere "enforcement" of some constitutional limitation imposed on the states. A simple example should make this plain. We return to the state obscenity law once again.

A state may criminalize obscenity, as we have previously noted, but of course it need not do so. Having once done so, moreover, it may later decide to repeal its anti-obscenity law. It may do so, to be sure, on account of a requirement in its own state constitution "free speech" clause-or it may do so from a belief that either the letter or spirit of the First and Fourteenth Amendments would be more faithfully carried into effect by doing so. But let us suppose that it reaches neither of these conclusions; let us suppose instead that it repeals its anti-obscenity law from no more a sublime (nor less excellent) reason than it might have in similarly deciding to repeal some of its criminal drug laws, namely, the conclusion that these laws simply tend to do more harm than good, that they spawn a heavy criminalized traffic (in drugs, or in obscene materials), that they stimulate criminal activities in much the same way that Prohibition did, and that it is simply time to take a different approach altogether (even as many believe to be warranted in respect to criminalized drugs).

In brief, from the state's view, the matter (as we are here stipulating it to be) is no different in constitutional terms than the state's decision to decriminalize commercial transactions in liquor and other alcoholic beverages. The state is perfectly aware that the Twenty-First Amendment permits it to be a "dry" state and, with that understanding, neither does it believe that there is any "fundamental right" of people to imbibe alcohol. Its decriminalization

\footnotetext{
receive such "protection" as the "built-in structural provisions" of the Constitution might offer (namely, protection at the pleasure of Congress, whatever it might be). This is the Wechsler-Choper thesis writ large. See JESSE H. CHOPER, JUDICIAL REVIEW AND THE National Polmitical Process 175-76 (1980); Jesse H. Choper, The Scope of National Power Vis-d-Vis the States: The Dispensability of Judicial Review, 86 YALE L.J. 1552, 1557 (1977); Herbert Wechsler, The Political Safeguards of Federalism: The Role of the States in the Composition and Selection of the National Government, 54 COLUM. L. REV. 543, 558-60 (1954); see also James B. Thayer, The Origin and Scope of the American Doctrine of Constitutional Law, 7 HARv. L. REV. 129, 130-44 (1893) (reviewing the origins of the power of courts to invalidate legislative acts, and advocating a highly deferential review). Professor Cohen also relied on Perez v. United States, 402 U.S. 146 (1971), to suggest that the thesis had been essentially accepted by the Supreme Court. See Cohen, supra note 64 , at 613 n.49. Understandably, he failed to anticipate that the Court might not agree. It does not. See, e.g., United States v. Lopez, 115 S. Ct. 1624 (1995); New York v. United States, 505 U.S. 144 (1992).
} 
of alcohol consumption, or of marijuana consumption, or-indeed-of obscenity consumption, is not and need not be driven by anything so sublime as some notion of constitutional entitlements, or any special desire to extend "liberty" as such. Rather, the state is driven by the practical conclusion that the current regime creates negative externalities that the state desires to avoid-which it then does, by taking a more relaxed, less regulatory, less draconian view. And all of this is perfectly sensible for the state to do.

Under the Cohen thesis, however, insofar as there is no constitutional barrier on the state's relaxation or outright abandonment of any of these, laws (and surely there is none), Congress could itself evidently step in and could sweep all the same state laws aside-at least with (and maybe even without?) pretense of doing so as an exercise of authority under Section 5 to enforce the "Liberty" Clause of Section 1. For, under the Cohen view (as a mere implementation of the Thayer-extended-by-Wechsler-extended-by-Choper view ${ }^{67}$, the Supreme Court appropriately abrogates federalism review in favor of Congress. ${ }^{68}$

Indeed, it is just this, too, that is also at stake, even as it was in earlier cases, as Justice Harlan, Alexander Bickel, and others have recognized all along. ${ }^{69}$ And it is also why the Court's own recent "federalism" decisions, New York v. United States, ${ }^{70}$ United States $v$. Lopez, ${ }^{71}$ and Seminole Tribe v. Florida, ${ }^{72}$ are significant as well. And so, too, as Bickel believed, are Marbury v. Madison $^{73}$ and McCulloch v. Maryland ${ }^{74}$ involved, respecting the role

67. See supra note 66 .

68. But see supra note 20 and accompanying text (noting the express rejection of such a proposal).

69. See Katzenbach v. Morgan, 384 U.S. 641, 666 (1966) (Harlan, J., dissenting) (excerpted supra at text accompanying note 63); Bickel, The Voting Rights Cases, supra note 20 , at 95-102; supra notes 20,50 , and 54.

70. 505 U.S. 144 (1992).

71. 115 S. Ct. 1624 (1995).

72. 116 S. Ct. 1114 (1996).

73. 5 U.S. (1 Cranch) 137 (1803).

74. 17 U.S. (4 Wheat.) 316, 423 (1819). In McCulloch, Chief Justice Marshall wrote: [S]hould Congress, under the pretext of executing its powers, pass laws for the accomplishment of objects not entrusted to the [national] government ... it would become the painful duty of this tribunal, should a case requiring such a decision come before it, to say that such an act was not the law of the land.

Id; see also 1 ALBERT J. BEVERDGE, THE LIFE OF JOHN MARSHALL 452 (1919) (remarks of John Marshall during the Virginia ratification debates) ("If . . . [Congress] were 
of the Court in keeping Congress within the boundary of its enumerated powers-in this instance, the power to "enforce" the provisions of the Fourteenth Amendment. ${ }^{75}$

C.

In his influential treatise, Professor Tribe presents two other views $^{76}$ and concludes strongly on a different view still:

It is not difficult to reconcile congressional power to define the content of fourteenth amendment rights with Marbury v. Madison and judicial review. Judicial review does not require that the Constitution always be equated with the Supreme Court's view of it. It is the Court's responsibility, under Marbury, to strike down acts of Congress which the Court concludes to be unconstitutional-nothing more. ${ }^{77}$

Of course, this is all true-artfully couched as it is with the appropriate (but merely nominal) nod to judicial review in its concluding observation. But it also quite begs the question (or, rather, asserts a premise that proves too much and is false). It is the Court's responsibility to strike down acts of Congress for which Congress can provide no authority to have enacted its will; this much Professor Tribe concedes. ${ }^{78}$ The question comes around then, still again: pursuant to what authority was this act adopted? What "provision" in the Fourteenth Amendment does the RFRA "enforce"? It is given this power, not some other; there is no power given to Congress "to define" the content of the Fourteenth Amendment however it may like.

Congress is given power to "define the content" of certain things, to be sure-for example, the power to determine the "content" of the rules by which it operates. ${ }^{79}$ Such provisions are

to make a law not warranted by any of the powers enumerated, it would be considered by the [National] judges as an infringement of the Constitution which they are to guard. They would not consider such a law as coming under their jurisdiction. They would declare it void.").

75. See Bickel, The Voting Rights Cases, supra note 20, at 97-98.

76. See TRIBE, supra note $64, \S 5-14$, at $345-48$ (outlining a total of four approaches to Justice Brennan's opinion in Katzenbach v. Morgan).

77. Id. $\$ 5-14$, at 349 (footnote omitted); see also Robin-Vergeer, supra note 45 , at 765 (citing the above passage from Tribe in her defense of the RFRA's constitutionality).

78. See TRIBE, supra note $64, \S 5-2$, at 298-300.

79. See U.S. CONST. art. I, \& 5, cl. 2 ("Each House may determine the Rules of its Proceedings."). 
twice instructive. They stand in contrast, not in parity, with the Fourteenth Amendment. They well indicate that Congress itself knows the difference. A mere rephrasing of Section 5 of the Fourteenth Amendment, so to provide just such a power in Congress-"to define the content of rights provided in Section 1"-is enough to make clear how utterly different it would look. And it makes clear how utterly implausible it is to suppose that any provision as thus proposed would-in 1868 or now-be ratified by the requisite number of states. ${ }^{80}$

In Marbury itself, note it could perfectly well be said that Congress was merely "enforcing" (if now translated as "defining the content of") a provision in Article III-namely, the provision that sketches the judicial power and then vests it in one Supreme Court and such inferior courts as Congress may provide. ${ }^{81}$ In vesting the judicial power in the Supreme Court, Article III goes on to vest it in that Court partly as a matter of original jurisdiction (two kinds of cases are specified), and partly as a matter of appellate jurisdiction, then authorizing Congress to place within the court's original jurisdiction some additional cases it deems appropriate to so place, excepting them from its appellate jurisdiction, where they would otherwise have remained. Or so at least one could readily read Article III; such a reading would not be, in any obvious way, "unreasonable." And if all that is required is that the Court be able to see "a reasonable basis" for the reading (i.e., the interpretation or the rendering) Congress provided, ${ }^{83}$ then in Marbury itself, the Court should have sustained the Judiciary Act provision that did precisely this very thing (though in its own view that reading of Article III was incorrect). As we know, however, the Court inquired into the constitutional interpretation on which the Judiciary Act depended for its validity; it took

80. See supra note 20 and accompanying text (noticing the rejection in Congress of a proposed draft of the Fourteenth Amendment that, even in its rejected terms, did not presume to confer this kind of power on Congress).

81. See U.S. CoNST. art. III, \& 1.

82. Such a reading of Article III is eminently plausible, though not the only reading, to be sure. Any court could perceive "a reasonable basis" so to understand Article III in just this way. See William W. Van Alstyne, A Critical Guide to Marbury v. Madison, 1969 DUKE L.J. 1, 30-33.

83. Compare Justice Brennan's formulation for the majority in Katzenbach v. Morgan, 384 U.S. 641, 653 (1966) (stating that it is not for the Supreme Court to review $\S 4(\mathrm{e})$ of the Voting Rights Act of 1965 beyond determining "a basis upon which the Congress might resolve the conflict [between federal and state interests] as it did"). 
Congress' view into account (always an appropriate matter to be sure); it disagreed with that interpretation (such as it was, as made by Congress); and it accordingly found that Congress had acted without authority (i.e., had acted in excess of any enumerated power) in providing as it had attempted to do.

In a larger sense, of course, the view that the Court should accept any "constitutional interpretation" of a clause that serves as a necessary predicate for some act of Congress whenever the Court can see "a reasonable basis" for that interpretation by Congress would at once virtually put an end to most of what makes the Supreme Court of the United States important-indeed, put an end to most of the institution of judicial review itself. For unless one can see at least a reasonable basis for a claim that some act or action by a state is contrary to some provision in the Constitution, the claim is unlikely to advance very far in the first place, much less advance to the Supreme Court.

To put the matter differently, it may correctly be said that we hardly need a Supreme Court just to rule on manifestly frivolous questions of constitutional law; rather, it is precisely in circumstances where "reasonable" people may (and do) differ that the unique resolving agency of the Supreme Court-to provide finality as well as stability-is most salient and most relevantly called upon to decide the matter. ${ }^{84}$

84. The point was put perfectly well by Justice Jackson, a half century ago, in the excerpted quotation prefacing this Essay. It is appropriate to repeat it here:

The generalities of the Fourteenth Amendment are so indeterminate as to what state actions are forbidden that this Court has found it a ready instrument, in one field or another, to magnify federal, and incidentally its own, authority over the states. . . . There is no doubt that if there were a super-Supreme Court, a substantial proportion of our [decisions respecting what the states may or may not do consistent with the Fourteenth Amendment] would also be reversed. We are not final because we are infallible, but we are infallible only because we are final.

Brown v. Allen, 344 U.S. 443, 534, 540 (1953) (Jackson, J., concurring). Obviously, Congress' ambition here is to deny that proposition, to declare that the Court is not "final" when it comes to saying what the states may not be permitted to do under the Fourteenth Amendment; rather, Congress is. And its ambition is to declare that if the Court will not read the "generalities" of the Fourteenth Amendment in a way satisfactory to "magnify" federal authority over the states, Congress will "reverse" the Court's decisions and so, as a super-Supreme Court, presume suitably to magnify that authority for itself. 
D.

Then, too, there is Professor Robin-Vergeer's seductive rephrasing in her own conclusion (as an incident of which she quotes from Tribe), namely that:

Under settled case law and the best understanding of its role on the constitutional stage, Congress has the power to enact legislation augmenting fundamental constitutional values beyond the level of protection the Supreme Court would require as a matter of constitutional law and displacing conflicting state laws, regardless of whether the federal legislation seemingly "contradicts" the narrower Supreme Court precedent. ${ }^{85}$

This, too, however, is essentially a mere figleaf of felicitous language (about "augmenting constitutional values") to make the RFRA go down with a spoonful of rhetorical sugar. The dead giveaway is discoverable in Professor Robin-Vergeer's use of the word "seemingly" - as though the matter were not one of any real difference at all. But that is plainly false. There is nothing merely "seemingly" contradictory here. The suggestion that perhaps "Supreme Court precedent" and the provisions of the RFRA are only seemingly at odds, but actually fully reconcilable, is belied on the face of the Act and in the President's own description of both its purpose and its intended effect. ${ }^{86}$

But, here, too, let us try it out in text; let us provisionally rewrite Section 5 straightforwardly, to say, for example:

The Congress shall have power to enforce its view of this article by appropriate legislation.

85. Robin-Vergeer, supra note 45 , at 764 (emphasis added).

86. See Appendix (reproducing full text of the RFRA); supra text accompanying note 3 (President Clinton's statement that the RFRA "reverses" Employment Discrimination $v$. Smith); see also Flores v. City of Boeme, 73 F.3d 1352, 1361 (5th Cir. 1996), cert. granted, 117 S. Ct. 293 (Oct. 15, 1996) (No. 95-2074) (describing the RFRA as "a substantive expansion" and "an assignment by Congress of a higher value to free-exercise-secured freedoms than the value assigned by the courts") (emphasis added).

Moreover, there is also in Professor Robin-Vergeer's formulation another question also too smoothly glossed over, namely, just what the "values" thus "augmented" are. These "values" may be merely in the beholder's own eye. What one person sees as the appropriate "accommodation" of "religious needs" by civil authority, others may equally well see (and be quite as correct in doing so) as the mere special privileging of those no more burdened by laws than anyone else, yet expecting and receiving privileged treatment. Which "values," then, does the RFRA "augment"? 
Or, if this seems somehow too strong, playing false to the more modest claim, then put it this way:

The Congress shall have power to enact legislation augmenting constitutional values it imputes to this article, and have such values as thus "augmented" by act of Congress applied as supreme law to regulate and to limit the states. ${ }^{87}$

If Section 5 read this way, even the first way, or if Section 5 were even meant to be understood in this way (though it does not say so), one might agree that the RFRA might be valid. ${ }^{88}$ It does not read this way, however, nor does it even suggest the thought. And again, if it did, if one encountered it for the first time as a seriously proposed amendment, one would surely raise some critical and serious questions, would one not?

E.

Still, to be sure, one can admit the Court itself may nevertheless interpolate such language (or invent such an "understanding") into the clause if it wishes; just as it may accept for itself a subordinate or even a sycophant role to Congress, ${ }^{89}$ and further abandon federalism review. ${ }^{90}$ It may do so, that is, despite the firm evidence that it was just this sort of substantive constitutional review (i.e., federalism review) that was most expected of the Supreme Court. It is-it was even ${ }^{91}$ in Morgan itself-largely a con-

87. (Though not to limit itself, except to such extent as Congress shall itself decide. See supra note 56 for a review of this self-exempting feature of the RFRA.)

88. However, one says "might" (rather than "would") advisedly, because, of course, the RFRA does not necessarily rest on any actual view of Congress regarding the Fourteenth Amendment or of any of its provisions at all. It may rest, rather, merely on what Congress preferred from an enthusiasm of its own: to preferentially befriend "religion," moved merely, as Congress so often appears to be moved, by the most ordinary and usual politics of the day and nothing more sublime. There is nothing to suggest that Congress even inquired into the particular provisions of the Fourteenth Amendment in fashioning the RFRA.

89. Which, unquestionably, sustaining the RFRA would clearly signal--for the Act makes no bones about its claim of entitlement to set aside the finality of Supreme Court adjudications of constitutional clauses, asserting an entitlement to substitute its own.

90. In some measure, no doubt, the Court has already done this, moreover, beginning with Katzenbach v. Morgan-although never in the sweeping manner and never to the degree so subordinating of the Court as that reflected in the RFRA. See Katzenbach v. Morgan, 384 U.S. 641,648 (1966).

91. And one says "even" advisedly; the act of Congress involved in Morgan did not involve nearly the breadth of Congress' claim as now asserted in the RFRA. See supra notes $50-62$ and accompanying text. 
stitutional tour de force scarcely anyone on the Court other than Justice Harlan found troubling. ${ }^{92}$ It was merely consistent with Justice Brennan's and others' general disposition to denigrate federalism review. ${ }^{93}$

This view of Section 5, permitting Congress to "reverse" the Court's Fourteenth Amendment decisions, however, was quite adequately disposed of by Bickel himself, in his review of Morgan, three decades ago. "Nothing is clearer about the history of the Fourteenth Amendment," he wrote, "than that its framers rejected the option of an open-ended grant of power to Congress to meddle with conditions within the states so as to render them equal in accordance with its own notions." Rather, he noted, "the framers chose to write an amendment empowering Congress only to rectify inequalities put into effect by the states. Hence the power of Congress comes into play only when the precondition of a denial of equal protection of the laws by a state has been met."

Bickel frankly expressed surprise at the Court's "abdication" of its proper judicial function even in the lesser degree reflected in Morgan itself. Still, at the time, he managed to conclude on a suitably professional and cautious note. "One doubts," he wrote, "that a new trend has really been inaugurated." Three decades later, the Court having quite carelessly offered Congress encouragement to deem itself nearly unlimited in constitutional authority, it seems clear that some kind of trend was inaugurated. And so the question now, as the RFRA wends its way through the federal court system, is whether it has any end.

92. See Morgan, 384 U.S. at 666 (Harlan, J., dissenting) (excerpted supra at text accompanying note 63 ).

93. See, e.g., Nat'I League of Cities v. Usery, 426 U.S. 833, 856 (1976) (Brennan, J., dissenting), overruled by Garcia v. San Antonio Metro. Transit Auth., 469 U.S. 528 (1985). This disposition is shared even now, perhaps, by four members of the current Court. See, e.g., the dissenting opinions in United States v. Lopez, 115 S. Ct. 1624 (1995), and New York v. United States, 505 U.S. 144 (1992).

94. See Bickel, The Voting Rights Cases, supra note 20, at 95-102.

95. Id. at 97.

96. Id. at 102 . 


\author{
APPENDIX \\ THE RELIGIOUS FreEDom Restoration ACT
}

42 U.S.C. § 2000bb (1994)

\title{
$\S 2000 \mathrm{bb}$. Congressional findings and declaration of purposes
}

\section{(a) Findings}

The Congress finds that-

(1) the framers of the Constitution, recognizing free exercise of religion as an unalienable right, secured its protection in the First Amendment to the Constitution;

(2) laws "neutral" toward religion may burden religious exercise as surely as laws intended to interfere with religious exercise;

(3) governments should not substantially burden religious exercise without compelling justification;

(4) in Employment Division v. Smith, 494 U.S. 872 (1990) the Supreme Court virtually eliminated the requirement that the government justify burdens on religious exercise imposed by laws neutral toward religion; and

(5) the compelling interest test as set forth in prior Federal court rulings is a workable test for striking sensible balances between religious liberty and competing prior governmental interests.

\section{(b) Purposes}

The purposes of this chapter are-

(1) to restore the compelling interest test as set forth in Sherbert v. Verner, 374 U.S. 398 (1963) and Wisconsin v. Yoder, 406 U.S. 205 (1972) and to guarantee its application in all cases where free exercise of religion is substantially burdened; and

(2) to provide a claim or defense to persons whose religious exercise is substantially burdened by government. 


\section{$\S 2000 \mathrm{bb}-1$. Free exercise of religion protected}

\section{(a) In general}

Government shall not substantially burden a person's exercise of religion even if the burden results from a rule of general applicability, except as provided in subsection (b) of this section.

\section{(b) Exception}

Government may substantially burden a person's exercise of religion only if it demonstrates that application of the burden to the person-

(1) is in furtherance of a compelling governmental interest; and

(2) is the least restrictive means of furthering that compelling governmental interest.

\section{(c) Judicial relief}

A person whose religious exercise has been burdened in violation of this section may assert that violation as a claim or defense in a judicial proceeding and obtain appropriate relief against a government. Standing to assert a claim or defense under this section shall be governed by the general rules of standing under article III of the Constitution.

\section{$\S 2000 b b-2$. Definitions}

As used in this chapter-

(1) the term "government" includes a branch, department, agency, instrumentality, and official (or other person acting under color of law) of the United States, a State, or a subdivision of a State;

(2) the term "State" includes the District of Columbia, the Commonwealth of Puerto Rico, and each territory and possession of the United States;

(3) the term "demonstrates" means meets the burdens of going forward with the evidence and of persuasion; and

(4) the term "exercise of religion" means the exercise of religion under the First Amendment to the Constitution. 


\section{$\S 2000 b b-3$. Applicability}

\section{(a) In general}

This chapter applies to all Federal and State law, and the implementation of that law, whether statutory or otherwise, and whether adopted before or after November 16, 1993.

\section{(b) Rule of construction}

Federal statutory law adopted after November 16, 1993, is subject to this chapter unless such law explicitly excludes such application by reference to this chapter.

\section{(c) Religious belief unaffected}

Nothing in this chapter shall be construed to authorize any government to burden any religious belief.

\section{$\S 2000 \mathrm{bb}-4$. Establishment clause unaffected}

Nothing in this chapter shall be construed to affect, interpret, or in any way address that portion of the First Amendment prohibiting laws respecting the establishment of religion (referred to in this section as the "Establishment Clause"). Granting government funding, benefits, or exemptions, to the extent permissible under the Establishment Clause, shall not constitute a violation of this chapter. As used in this section, the term "granting", used with respect to government funding, benefits, or exemptions, does not include the denial of government funding, benefits, or exemptions. 